\title{
Análise do procedimento de simulação da NBR 15575 para avaliação do desempenho térmico de edificações residenciais
}

\author{
Analysis of the NBR 15575 simulation procedure in \\ assessing the thermal performance of dwellings
}

\section{Marcio José Sorgato \\ Ana Paula Melo \\ Deivis Luís Marinoski \\ Roberto Lamberts}

\section{Resumo}

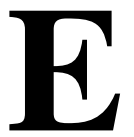

ste estudo tem por objetivo avaliar o procedimento indicado na NBR15575-1 (ABNT, 2013a) para simulação do desempenho térmico de edificações residenciais. Para a análise, adotou-se uma edificação unifamiliar para os climas das cidades de Florianópolis, Curitiba e São Luís. A simulação computacional foi realizada através do programa EnergyPlus. A investigação analisou a influência das condições do piso da edificação em contato com o solo no resultado do desempenho térmico para verão e inverno, uma vez que a NBR 15575-1 (ABNT, 2013a) não especifica esse parâmetro. Foi também observada a influência dos parâmetros sombreamento e renovação de ar com base no procedimento simplificado da NBR 15575-1 (ABNT, 2013a). Por último, aplicou-se a proposta de um novo procedimento de simulação para avaliar o desempenho térmico de edificações residenciais, tendo-se comparado os resultados encontrados com os resultados do procedimento atual da NBR 15575-1 (ABNT, 2013a). As comparações entre os dois procedimentos indicaram, principalmente, que as modificações nas condições de contato com o solo exercem forte influência nos resultados das simulações do desempenho térmico da edificação e, consequentemente, na aprovação do sistema construtivo em análise.

Marcio José Sorgato Universidade Federal de Santa Catarina

Florianópolis - SC - Brasil

Ana Paula Melo Universidade Federal de Santa Catarina

Florianópolis - SC - Brasil

Deivis Luís Marinoski Universidade Federal de Santa Catarina

Florianópolis - SC - Brasil

Roberto Lamberts Universidade Federal de Santa Catarina

Florianópolis - SC - Brasil

Recebido em 14/03/14 Aceito em 29/08/14
Palavras-chaves: NBR 15575. Simulação computacional. Desempenho térmico. Edificações residenciais.

\section{Abstract}

This aim of this study is to evaluate the simulation procedure proposedby NBR 15575-1 (ABNT, 2013a) to assess the thermal performance of dwellings. A single family dwelling considering the climates of Florianópolis, Curitiba and São Luís was adopted. A computer simulation was performed using the EnergyPlus programme. The investigation analysedthe influence of the building ground slab contact conditions on the thermal performance results for both summer and winter, as the NBR 15575-1 (ABNT, 2013a) does not specify this parameter. In addition, the influence of the parameters shading and air exchange was observed, based on a simplified procedure from NBR 15575-1 (ABNT, 2013a). Finally, a proposal for a new simulation procedure to evaluate the thermal performance of residential buildings was assessed, comparing its results with those of the current procedures ofNBR 15575-1 (ABNT, 2013a). The comparison of results indicatedthat the conditions of the ground slab contact conditions selected to simulate the thermal performance of the building strongly influenced the constructive system analysis. The comparison between the two procedures showed a difference in the performance results of the dwelling, considering the same building component.

Keywords: NBR 15575. Computational simulation. Thermal performance.Residential buildings. 


\section{Introdução}

A aplicação de algumas tecnologias recentemente introduzidas no setor da construção civil tem gerado, por vezes, dúvidas sobre a qualidade das edificações. No entanto, é consenso que as habitações devam proporcionar conforto e segurança a seus usuários, atendendo a suas necessidades ao longo do ciclo de vida das construções.

Nesse cenário, ao longo das últimas décadas, diversos países ao redor do mundo têm-se empenhado para ampliar o embasamento científico e a criação de normas de desempenho para edificações. Já em 1953 foi fundado o Council International for Buildings (CIB), o qual tinha por finalidade a abordagem do desempenho de edificações, estabelecendo a troca de informações entre países para constituir uma estrutura conceitual que pudesse ser adotada por todos. A posterior implementação de normas para o setor tem, então, agregado mais qualidade na concepção, elaboração e execução dos projetos, visando às necessidades dos usuários.

No Brasil a preocupação com o desempenho mínimo das edificações ganhou espaço em anos recentes e foi expressa de forma documental na publicação da norma NBR 15575, norma que estabelece requisitos mínimos de desempenho, vida útil e de garantia para os principais sistemas que compõem as edificações. A NBR 15575 teve sua primeira versão publicada pela ABNT em 2008. Sendo alvo de muitas discussões, foi revisada em 2010, 2012 e 2013. Apesar de possuir quatro versões, a norma de desempenho entrou em vigor apenas em 19 de fevereiro de 2013, válida a partir de 19 de julho do mesmo ano.

Um dos tópicos que gerou grande expectativa e interesse na norma brasileira é o quesito desempenho térmico. Isso se justifica porque, nos anos recentes, a busca por soluções arquitetônicas energeticamente eficientes e climaticamente adequadas é um tema preeminente no Brasil e no mundo (HENSEN; LAMBERTS, 2011). Além disso, países como os Estados Unidos e a França já instituíram seus regulamentos de desempenho térmico e energético desde meados dos anos 1980 (FRANÇA, 1988; AMERICAN..., 1989).

Segundo a pesquisa realizada por Janda e Busch (1992) com relação ao conteúdo de normas de desempenho termoenergético, a maioria dos países levou em consideração a combinação das exigências prescritivas e de avaliação do projeto na elaboração de suas normativas. A NBR 15575-1 (ABNT, 2013a) estabeleceu três procedimentos para a avaliação do desempenho térmico das edificações: procedimento simplificado, simulação e medição. No procedimento simplificado, verifica-se o atendimento aos requisitos e critérios para fachadas e coberturas, indicados nos textos da NBR 15575-4 (ABNT, 2013b) e NBR 15575-5 (ABNT, 2013c). Caso a edificação não atinja os requisitos estabelecidos por esse primeiro procedimento, recorre-se ao procedimento de simulação ou medição. No procedimento de simulação, verifica-se o atendimento aos requisitos e critérios estabelecidos na Parte 1 desta norma, através do uso de softwares de simulação computacional. No procedimento de medição, ocorre a verificação do atendimento aos requisitos e critérios estabelecidos também na Parte 1, mas por meio da realização de avaliações in loco (na própria edificação ou em protótipos).

O procedimento simplificado da norma, apesar de ser uma ferramenta de aplicação rápida, pode apresentar incertezas consideráveis em seus resultados. Grigoletti e Sattler (2010) comentam que, embora a NBR 15575 tenha sido um passo importante para a melhoria do desempenho térmico das construções no Brasil, o procedimento simplificado detém-se apenas em paredes e coberturas, e não na edificação como um todo. Sendo assim, essa análise isolada pode não expressar o comportamento térmico real de edificação. Este e outros fatores levaram à realização de estudos de avaliação da NBR 15575 , referentes ao desempenho térmico. Loura, Assis e Bastos (2011) realizaram uma análise comparativa entre resultados de desempenho térmico da envoltória de um edifício residencial gerados por diferentes normas brasileiras, incluindo a NBR 15575. Brito et al. (2012) apresentaram contribuições para o aprimoramento do procedimento simplificado com base em valores do parâmetro transmitância e capacidade térmica de elementos construtivos para as coberturas. Oliveira, Souza e Silva (2013) compararam os valores de algumas propriedades prescritas para paredes e coberturas do procedimento simplificado da NBR 15575 com os parâmetros indicados em outras normas e regulamentos nacionais vigentes, tendo observado divergência entre estes.

Já Sorgato et al. (2012) apresentaram sugestões e críticas à NBR 15575-1, NBR 15575-4 e NBR 15575-5 (ABNT, 2013a, 2013b, 2013c). Entre os pontos observados, destacou-se a não avaliação do uso real da edificação sob avaliação e a não avaliação da influência da variação anual da temperatura no desempenho térmico da edificação. Marques e Chvatal (2013) desenvolveram uma pesquisa que analisou o procedimento simplificado 
e de simulação de desempenho térmico da NBR 15575-1 (ABNT, 2013a). Os resultados mostraram limitações no atual procedimento de simulação relacionadas aos arquivos climáticos e estratégias passivas, e inconsistências com o procedimento simplificado. $\mathrm{O}$ trabalho evidencia a necessidade de melhoramento da norma. Em outro estudo, Sorgato, Melo e Lamberts (2013) mostraram que a avaliação do desempenho térmico de edificações residenciais através do procedimento de simulação da NBR 15575-1 (ABNT, 2013a) é diretamente influenciada pela configuração dos dias típicos de verão e de inverno. A falta de algumas informações como o tipo de céu e a data do dia típico de projeto são parâmetros importantes para calcular a irradiação solar a que a edificação está exposta e, dependendo da configuração, pode viabilizar ou não a aprovação de um sistema construtivo.

Com base nessas observações, verifica-se a importância de avaliar o procedimento de simulação presente na atual versão (2013) da NBR 15575-1 (ABNT, 2013a) e, com referência nos resultados, avaliar a proposta de um novo procedimento de simulação para a análise do desempenho térmico das edificações residenciais, sendo este o objetivo deste trabalho.

\section{Método}

Para o estudo proposto, o procedimento de simulação da NBR-15575-1 (ABNT, 2013a) foi analisado e comparado com o procedimento proposto por Sorgatoet al. (2012). Para o desenvolvimento do estudo, adotou-se um casobase variando-se valores de parâmetros que não são considerados na avaliação do desempenho térmico da NBR 15575-1 (ABNT, 2013a): o contato com o solo e a temperatura do solo. Com base nos resultados, foi possível comparar a influência destes parâmetros nos resultados referentes ao desempenho térmico da edificação. Ressalta-se que os casos foram simulados conforme as recomendações e exigências de ambos os procedimentos.

\section{Características da modelagem da edificação}

A avaliação do desempenho térmico foi realizada em uma edificação residencial unifamiliar com área construída de $36 \mathrm{~m}^{2}$, com dimensões de $6,0 \mathrm{~m}$ x 6,0 m x 2,8 m. A edificação é composta de dois dormitórios, banheiro, sala e cozinha conjugada. Para o estudo, foram considerados os climas das cidades de Curitiba (zona bioclimática 1), Florianópolis (zona bioclimática 3) e São Luís (zona bioclimática 8). A Figura 1 apresenta o croqui volumétrico e da planta baixa da edificação.

A cobertura da edificação é composta de telha cerâmica, barreira radiante de alumínio e laje armada em blocos cerâmicos. As paredes são de concreto armado moldadas in loco, com espessura total de $5 \mathrm{~cm}$. As propriedades térmicas das paredes e cobertura são apresentadas na Tabela 1.

O tamanho da abertura para ventilação e iluminação é de $15 \%$ em relação à área do ambiente, e as aberturas dos ambientes de permanência prolongada possuem dispositivos de sombreamento externo (venezianas). A abertura é sombreada através das venezianas, no período do verão, das $8 \mathrm{~h}$ às $18 \mathrm{~h}$.

Todos os ambientes da edificação foram simulados com 1 (uma) renovação de ar por hora. O piso da edificação está em contato com o solo, e os valores de temperatura do solo foram obtidos do arquivo climático de cada cidade. Para a simulação da tipologia utilizaram-se os arquivos climáticos das cidades de Curitiba, Florianópolis e São Luís, do tipo TRY (Test Referency Year), de 1969, 1963 e 1966 respectivamente. Esses arquivos incluem dados de cada região adotada e representam um ano climático médio dentro de uma série de 10 anos (GOULART, 1993).

Para a análise do desempenho térmico foi adotado o programa de simulação computacional EnergyPlus, versão 7.2 (DEPARTMENT..., 2012). Esse programa é validado pela ANSI/ASHRAE Standard 140 (AMERICAN..., 2011), atendendo ao critério estabelecido na NBR 15575-1 (ABNT, 2013a).

As características do caso-base podem ser observadas na Tabela 1.

\section{Procedimento de simulação do desempenho térmico da NBR15575}

A NBR 15575-1 (ABNT, 2013a) estabelece que o desempenho térmico da edificação deve ser avaliado para duas condições: desempenho no verão e desempenho no inverno. O critério da análise é baseado em valores máximos e mínimos de temperatura dos ambientes de permanência prolongada. A norma recomenda que o desempenho da edificação seja avaliado em um ambiente de permanência prolongada (dormitório ou sala de estar) para a condição crítica do ponto de vista térmico. 
Figura 1 - Croqui volumétrico da edificação e o croqui da planta baixa da edificação

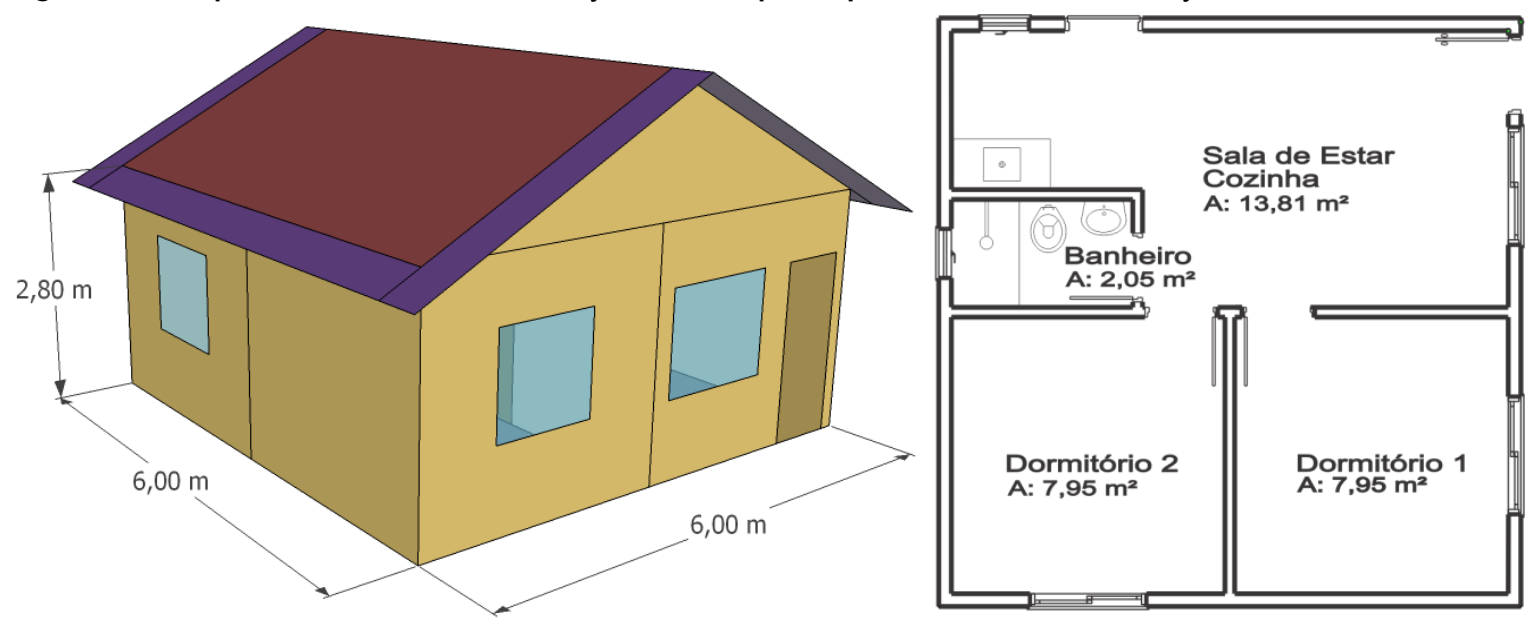

Tabela 1 - Características do caso-base

\begin{tabular}{lc}
\hline \multicolumn{1}{c}{ Parâmetros } & Características do caso-base \\
\hline Transmitância térmica das paredes & $5,00 \mathrm{~W} / \mathrm{m}^{2} \mathrm{~K}$ \\
Absortância à radiação solar das paredes & 0,30 \\
Capacidade térmica das paredes & $120,0 \mathrm{~kJ} / \mathrm{m}^{2} \mathrm{~K}$ \\
Transmitância térmica da cobertura & $1,09 \mathrm{~W} / \mathrm{m}^{2} \mathrm{~K}$ \\
Absortância à radiação solar da cobertura & 0,50 \\
Capacidade térmica da cobertura & $113,0 \mathrm{~kJ} / \mathrm{m}^{2} \mathrm{~K}$ \\
Sombreamento externo & Sim - durante o verão \\
Temperatura do solo & Do arquivo climático \\
Taxa de renovação do ar & 1 renovação por hora \\
\hline
\end{tabular}

Para a avaliação do desempenho no verão, o ambiente de permanência prolongada deve apresentar temperaturas menores ou iguais às externas para o dia típico de verão. O pico da temperatura no interior do ambiente deve ser menor ou igual ao pico de temperatura do ar exterior. A edificação deve ser simulada sem a consideração de cargas internas (ocupação, iluminação e equipamentos), conforme recomendado pela NBR 15575-1 (ABNT, 2013a). $\mathrm{O}$ ambiente selecionado para a análise no verão foi o dormitório com a janela orientada para oeste e a outra parede voltada para norte (Dormitório 1).

Para a avaliação do desempenho no inverno, a edificação deve apresentar valores mínimos diários da temperatura interna do ar maiores ou iguais à temperatura mínima externa acrescida de $3{ }^{\circ} \mathrm{C}$. Para o período de inverno, a NBR 15575-1 (ABNT, 2013a) não estabelece se a edificação deve ser avaliada com ou sem cargas internas. Neste estudo, todos os casos foram simulados sem cargas internas na avaliação do desempenho térmico de inverno. $\mathrm{O}$ ambiente selecionado para a análise foi o dormitório com a janela orientada para sul e a outra parede para leste (Dormitório 1).
O desempenho térmico foi avaliado para o dia típico de verão e inverno para as cidades de Florianópolis, Curitiba e São Luís, conforme os dados da Tabela A.2 e da Tabela A.3 da NBR15575-1 (ABNT, 2013a). Ressalta-se que essas tabelas não apresentam informações referentes à data e ao tipo de céu para simular um dia de projeto, assim como o valor da radiação solar para o clima da cidade de Florianópolis (SORGATO; MELO; LAMBERTS, 2013).

Portanto, com base no estudo realizado por Sorgato, Melo e Lamberts (2013), optou-se por adotar o valor de $100 \%$ de céu limpo para a simulação do dia típico de verão, e para o dia típico de inverno adotou-se $40 \%$ de céu limpo. Com relação às datas, adotaram-se o dia 21 de dezembro (solstício de verão) e o dia 21 de junho (solstício de inverno).

Com relação aos dados de entrada no programa de simulação, optou-se por analisar diferentes condições do piso da edificação em contato com o solo, uma vez que a NBR 15575-1 (ABNT, 2013a) não especifica esse parâmetro. As condições do piso da edificação em contato com o solo são apresentadas na Tabela 2. Entre as condições, 
adotaram-se as temperaturas do solo presente no arquivo climático, o piso adiabático (sem troca de calor entre o solo e o piso) e o acréscimo e diminuição de $2{ }^{\circ} \mathrm{C}$ das temperaturas do solo do arquivo climático. Esta última condição foi adotada como referência da interação do uso do pré-processador Slab do programa EnergyPlus. O pré-processador Slab simula a influência que o solo exerce nas temperaturas da edificação e viceversa (MAZZAFERRO et al., 2014).

Na Tabela 3 são apresentadas as temperaturas do solo utilizadas nas simulações do dia típico de verão e inverno para as cidades de Curitiba, Florianópolis e São Luís. Ressalta-se que a temperatura do solo no inverno para a cidade de São Luís não foi apresentada, pois o desempenho térmico no inverno não é avaliado em São Luís.

\section{Caso do procedimento simplificado}

Foram também considerados três diferentes casos com base nos requisitos e critérios do procedimento simplificado proposto pela NBR 15575. As características de cada caso podem ser observadas na Tabela4. No procedimento simplificado, os sistemas de vedação e cobertura devem atender aos requisitos e critérios conforme a NBR 15575-4 (2013b) e NBR 15575-5 (2013c). Além do parâmetro condições de contato com o solo, também foram avaliados os parâmetros sombreamento e taxa de renovação de ar.

\section{Procedimento de simulação proposto}

Sorgato et al. (2012) apresentaram a proposta de um procedimento de simulação para avaliar o desempenho térmico da envoltória de edificações residenciais. $\mathrm{O}$ procedimento proposto busca avaliar o desempenho térmico, considerando a realidade de uso das edificações residenciais.

Esse método salienta que a edificação sob avaliação deve ser modelada de acordo com o projeto arquitetônico, considerando cargas internas de ocupação e iluminação. Já a edificação de referência deve atender aos limites estabelecidos no procedimento simplificado da NBR 15575 (ABNT, 2013b, 2013c), para os valores de transmitância térmica da parede e cobertura, conforme a zona bioclimática de implantação do projeto. As aberturas dos dormitórios da edificação de referência devem ser modeladas com dispositivo de sombreamento, quando existentes.

Tabela 2 - Condições de contato com o solo

\begin{tabular}{lc}
\hline \multicolumn{1}{c}{ Casos } & Condições de contato com o solo \\
\hline Dormitório - Base & Temperaturas do solo do arquivo climático \\
Dormitório - Temp. solo $+2{ }^{\circ} \mathrm{C}$ & Temperaturas do solo do arquivo climático $+2{ }^{\circ} \mathrm{C}$ \\
Dormitório - Temp. solo $-2{ }^{\circ} \mathrm{C}$ & Temperaturas do solo do arquivo climático $-2{ }^{\circ} \mathrm{C}$ \\
Dormitório - Piso adiabático & Piso adiabático \\
\hline
\end{tabular}

Tabela 3 - Temperaturas do solo nos meses do dia típico de verão e de inverno

\begin{tabular}{cccccc}
\hline \multirow{2}{*}{ Temperatura do solo $\left({ }^{\circ} \mathrm{C}\right)$} & \multicolumn{2}{c}{ Curitiba } & \multicolumn{2}{c}{ Florianópolis } & São Luís \\
\cline { 2 - 6 } & Verão & Inverno & Verão & Inverno & Verão \\
\hline Arquivo climático & 18,56 & 14,20 & 22,01 & 19,38 & 26,97 \\
Arquivo climático $+2{ }^{\circ} \mathrm{C}$ & 20,56 & 16,20 & 24,01 & 21,38 & 28,97 \\
Arquivo climático $-2{ }^{\circ} \mathrm{C}$ & 16,56 & 12,20 & 20,01 & 17,38 & 24,97 \\
\hline
\end{tabular}

Tabela4 - Casos com base no procedimento simplificado da NBR 15575

\begin{tabular}{ll}
\hline \multicolumn{1}{c}{ Casos } & \multicolumn{1}{c}{ Método simplificado } \\
\hline $\begin{array}{l}\text { Dormitório - Simplificado, sem } \\
\text { sombreamento, 1 renovação }\end{array}$ & $\begin{array}{l}\text { Caso base + transmitância térmica parede do procedimento } \\
\text { simplificado + sem sombreamento + 1 renovação de ar por hora }\end{array}$ \\
\hline $\begin{array}{l}\text { Dormitório - Simplificado, sem } \\
\text { sombreamento, 5 renovações }\end{array}$ & $\begin{array}{l}\text { Caso base + transmitância térmica parede do procedimento } \\
\text { simplificado + sem sombreamento + taxa de renovação de 5 } \\
\text { trocas de ar por hora }\end{array}$ \\
\hline $\begin{array}{l}\text { Dormitório - Simplificado, sem } \\
\text { sombreamento, piso adiabático }\end{array}$ & $\begin{array}{l}\text { Caso simplificado da NBR 15575 (ABNT, 2013a) + piso } \\
\text { adiabático + 1 renovação de ar por hora }\end{array}$ \\
\hline
\end{tabular}

Fonte: ABNT (2013a). 
O procedimento proposto recomenda que o desempenho da edificação ventilada naturalmente seja avaliado por meio dos indicadores de graushora de resfriamento $\left({ }^{\circ} \mathrm{Ch}_{\mathrm{R}}\right)$ e graus-hora de aquecimento $\left({ }^{\circ} \mathrm{Ch}_{\mathrm{A}}\right)$. Os ambientes de permanência prolongada devem ser avaliados por meio da comparação entre o desempenho térmico da edificação sob avaliação e o desempenho térmico da edificação de referência. Assim, os indicadores de ${ }^{\circ} \mathrm{Ch}_{\mathrm{R}}$ e ${ }^{\circ} \mathrm{Ch}_{\mathrm{A}}$ dos ambientes de permanência prolongada da edificação sob avaliação devem ser iguais ou menores que os graus-hora de resfriamento e os graus-hora de aquecimento da edificação de referência, para que seja atingida a condição mínima de desempenho satisfatório.

\section{Estratégia de ventilação natural}

A estratégia de ventilação natural adotada na simulação foi mediante o controle de ventilação seletiva, que permite abrir as janelas conforme dois critérios de temperatura. Uma Schedule de temperatura controla a abertura das janelas, na qual habilita a abertura quando a temperatura do ar do ambiente é igual ou superior à temperatura estabelecida $\left(\mathrm{T}_{A m b} \geq \mathrm{T}_{\text {Estabelecida }}\right)$ e quando a temperatura do ambiente é superior à externa $\left(\mathrm{T}_{A m b}\right.$ $\geq \mathrm{T}_{E x t}$ ). A temperatura estabelecida foi de $20^{\circ} \mathrm{C}$.

\section{Cargas internas}

O padrão de ocupação (Figura 2a) representa uma família composta de quatro moradores: um casal e dois filhos. No período das $9 \mathrm{~h}$ às $18 \mathrm{~h}$ duas pessoas permanecem na residência. A sala/cozinha é utilizada por toda a família, e a ocupação máxima dos dormitórios é de duas pessoas. O padrão de iluminação (Figura 2b) da residência está vinculado ao padrão de ocupação. Considerou-se que os usuários aproveitam a iluminação natural durante parte do período diurno, acionando a iluminação artificial somente no início da manhã e no final da tarde durante o período diurno ( $8 \mathrm{~h}$ às 18h). O banheiro da residência não foi considerado como um ambiente ocupado, devido a ser um ambiente de curta permanência dos usuários durante o dia.

No dormitório, a carga interna referente à ocupação foi de $81 \mathrm{~W} /$ pessoa; na sala de estar, de $108 \mathrm{~W} /$ pessoa; e na cozinha, de $171 \mathrm{~W} /$ pessoa. No horário das refeições, quando a sala/cozinha é ocupada por mais de uma pessoa, somente um usuário estará com carga interna de $171 \mathrm{~W} /$ pessoa. Nos dormitórios e na sala de estar/cozinha, adotouse densidade de potência de iluminação artificial de $5,0 \mathrm{~W} / \mathrm{m}^{2}$.

\section{Sombreamento das aberturas}

O dispositivo de sombreamento das aberturas foi modelado através de uma veneziana horizontal. A modelagem no programa de simulação é realizada através do objeto Exterior Blind. Para as cidades de Curitiba e Florianópolis considerou-se que as aberturas estão sombreadas no período de 21 de setembro a 20 de março (no horário das 8 h às 18 h) compreendendo a primavera e o verão. Já para São Luís considerou-se que as aberturas estão sombreadas o ano inteiro (no horário das $8 \mathrm{~h}$ às $18 \mathrm{~h})$.

\section{Análise dos resultados}

\section{Procedimento de simulação do desempenho térmico da NBR 15575}

\section{Contato com o solo}

As Figura 3, 4 e 5 apresentam a influência do piso do ambiente em contato com o solo no desempenho térmico da edificação para o dia típico de verão e de inverno, para os climas das cidades de Curitiba, Florianópolis e São Luís respectivamente.

Observa-se que no dia típico de verão para o clima de Curitiba a variação da temperatura do solo em $\pm 2{ }^{\circ} \mathrm{C}$ impactou em uma diferença de $\pm 0,5^{\circ} \mathrm{C}$ na temperatura do ambiente em Curitiba em relação ao Dormitório - Base (que adota a temperatura do solo presente no arquivo climático). Em relação ao Dormitório - Piso adiabático, nota-se que há aumento na temperatura do ambiente em aproximadamente $3,5^{\circ} \mathrm{C}$. Para o dia típico de verão para o clima de Curitiba, o Dormitório Base (parede de concreto $5 \mathrm{~cm}$ ) atende ao critério de desempenho térmico mínimo para o verão, quando o piso do ambiente está em contato com o solo. No caso do Dormitório - Piso adiabático, observa-se que este não atende ao critério estabelecido no método de simulação da NBR 15575-1 (ABNT, 2013a). Para o dia típico de inverno, a variação da temperatura do solo impactou na temperatura do ambiente em aproximadamente $0,7{ }^{\circ} \mathrm{C}$. No caso Dormitório Base, a temperatura mínima do ambiente foi de 6,0 ${ }^{\circ} \mathrm{C}$, sendo a temperatura mínima externa de $0,8^{\circ} \mathrm{C}$. Para este caso, a diferença entre a temperatura mínima interna e a externa foi de $5,2^{\circ} \mathrm{C}$.

O nível do desempenho de acordo com a NBR 15575 para cada um dos casos analisados para a cidade de Curitiba é apresentado na Tabela 5. Observa-se que, dependendo da condição do piso adotado nas simulações, os níveis de acordo com a NBR 15575-1 (ABNT, 2013a) podem variar de "Não atendem ao nível mínimo" a "Intermediário". 
Essas variações demonstram que, dependendo da condição de contato com o solo selecionada para a simulação, o desempenho térmico da edificação pode ser aprovado ou reprovado.

No dia típico de verão para o clima de Florianópolis (Figura 4), observa-se que a temperatura máxima do ambiente do caso Dormitório - Base é de $32,7{ }^{\circ} \mathrm{C}$, igual à temperatura máxima externa. $\mathrm{A}$ variação da temperatura do solo em $+2{ }^{\circ} \mathrm{C}$ aumentou a temperatura máxima do dormitório para $33,3{ }^{\circ} \mathrm{C}$, resultando em temperatura superior à máxima externa. Entretanto, a redução de $-2{ }^{\circ} \mathrm{C}$ na temperatura do solo reduziu a temperatura máxima do dormitório para $32,2{ }^{\circ} \mathrm{C}$, resultando em uma diferença de $0,5^{\circ} \mathrm{C}$ com relação ao Dormitório Base. No caso Dormitório - Piso Adiabático há aumento da temperatura do ambiente em relação ao caso Dormitório - Base, e a temperatura máxima do ambiente excedeu em $2,7{ }^{\circ} \mathrm{C}$ a temperatura máxima externa. No dia típico de inverno para o clima de Florianópolis, a diferença entre a temperatura mínima interna e externa foi de $4,4{ }^{\circ} \mathrm{C}$ no caso Dormitório - Base. O caso que apresentou a maior diferença entre a temperatura mínima interna e a externa foi o caso Dormitório Temp. solo, $+2{ }^{\circ} \mathrm{C}\left(5,1^{\circ} \mathrm{C}\right)$. Já o caso com menor diferença $\left(0,8{ }^{\circ} \mathrm{C}\right)$ foi o caso Dormitório - Piso adiabático.

Figura 2 - Padrão de ocupação e iluminação artificial

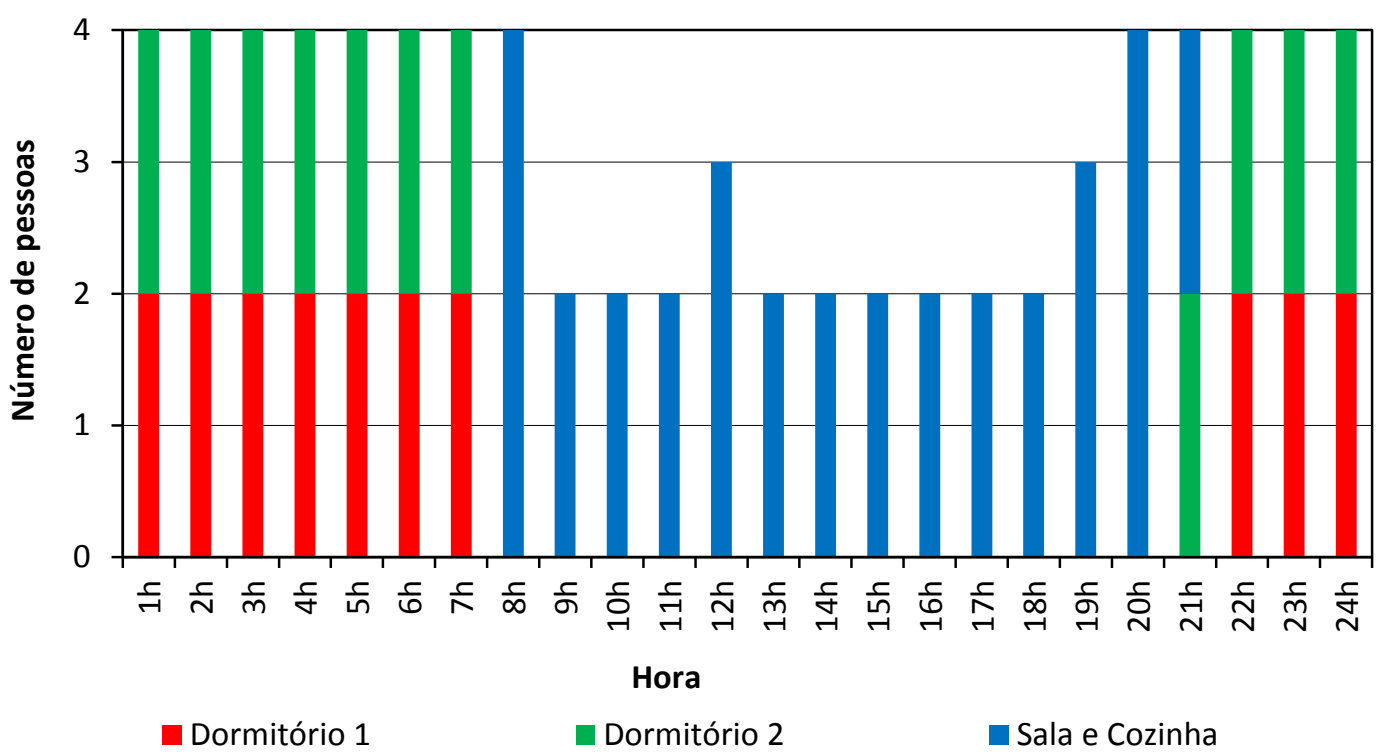

(a) Padrão de ocupação

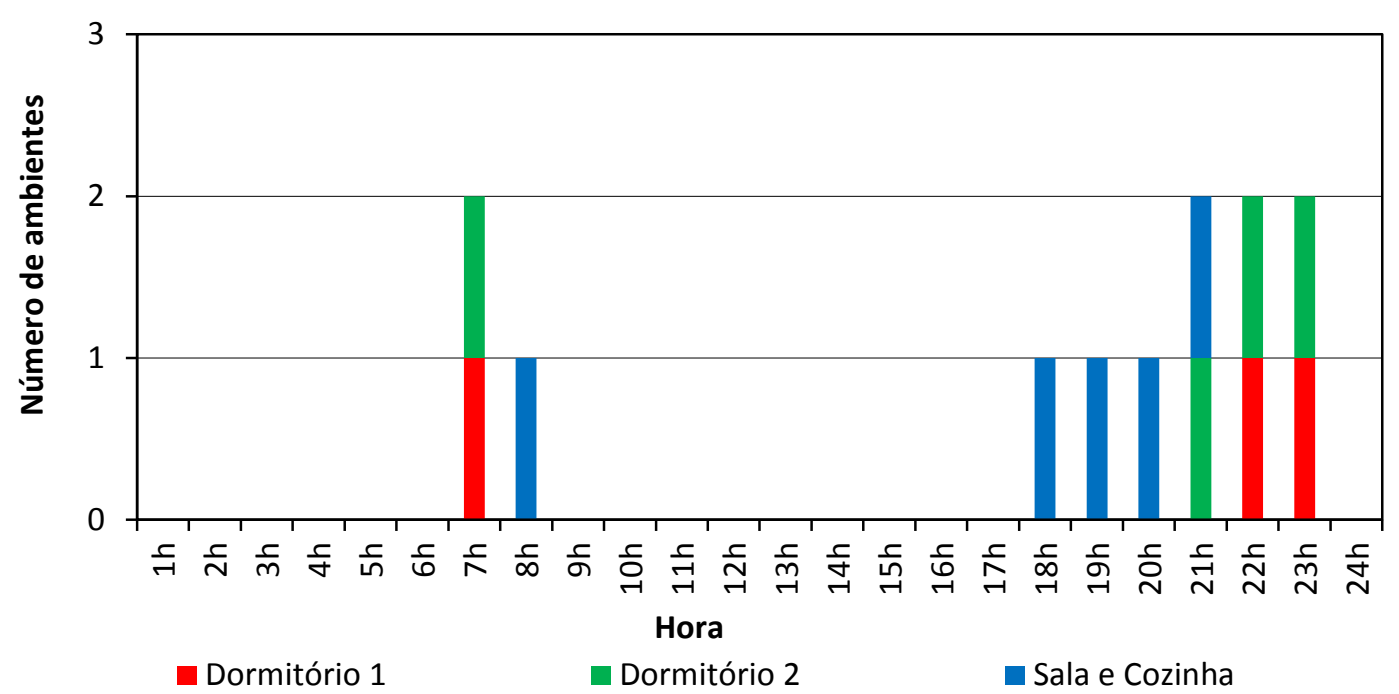

(b) Padrão de iluminação artificial 
Figura 3 - Influência do contato com o solo no desempenho do dormitório no dia típico de verão e inverno para o clima de Curitiba
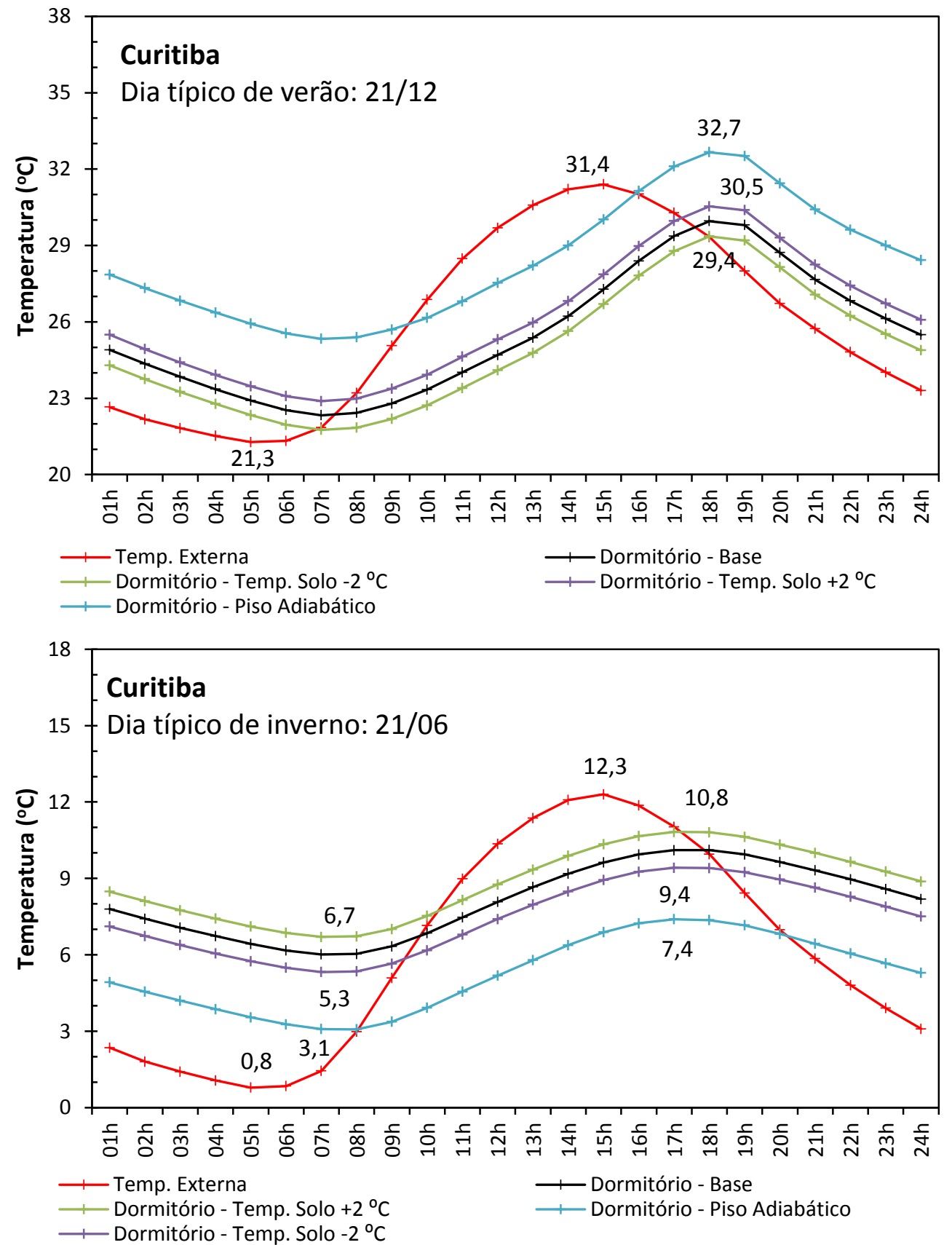

Tabela 5 - Contato com o solo - dia típico de verão e inverno para o clima de Curitiba

\begin{tabular}{lcc}
\hline \multicolumn{1}{c}{ Casos } & \multicolumn{2}{c}{ Nível de desempenho NBR 15575-1 (ABNT, 2013a) } \\
\cline { 2 - 3 } & Dia típico de verão & Dia típico de inverno \\
\hline Dormitório - Base & Mínimo & Intermediário \\
Dormitório - Temp. solo $+2{ }^{\circ} \mathrm{C}$ & Mínimo & Intermediário \\
Dormitório - Temp. solo $-2{ }^{\circ} \mathrm{C}$ & Intermediário & Mínimo \\
Dormitório - Piso adiabático & Não atende ao nível mínimo & Não atende ao nível mínimo \\
\hline
\end{tabular}

90 Sorgato, M. J.; Melo, A. P.; Marinoski, D. L.; Lamberts, R 
Figura 4 - Influência do contato com o solo no desempenho do dormitório no dia típico de verão e inverno para o clima de Florianópolis
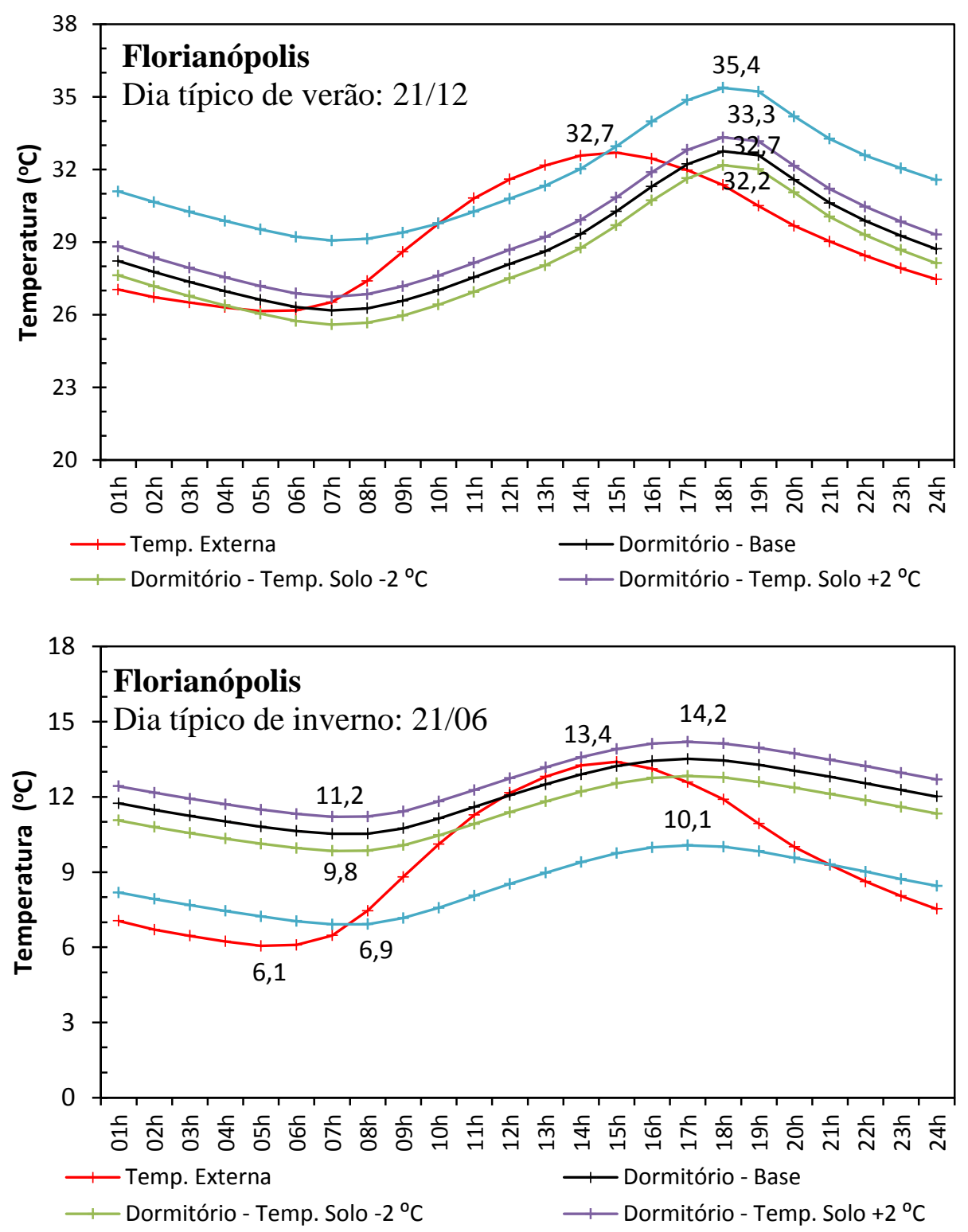

O resumo dos níveis de desempenho dos casos de Florianópolis no dia típico de verão e inverno é apresentado na Tabela 6 . As variações no nível de desempenho demonstram novamente que, dependendo da condição de contato com o solo selecionada para a simulação, o desempenho térmico da edificação pode ser aprovado ou reprovado. Observa-se que somente o Dormitório Base e o Dormitório - Temp. solo $-2{ }^{\circ} \mathrm{C}$ atenderam ao critério de desempenho térmico mínimo para o dia típico de verão. Para o dia típico de inverno, todos os casos atenderam à norma, exceto o ambiente simulado com piso adiabático.
Nos resultados do dia típico de verão para o clima de São Luís (Figura 5), todos os casos simulados apresentaram a temperatura máxima do ambiente superior à temperatura máxima externa. $\mathrm{O}$ caso Dormitório - Piso adiabático atingiu a temperatura mais elevada $\left(34,1^{\circ} \mathrm{C}\right)$, e o Dormitório - Temp. solo $-2{ }^{\circ} \mathrm{C}$, a menor temperatura $\left(32,6^{\circ} \mathrm{C}\right)$ entre os casos. Nota-se que o caso Dormitório - Piso adiabático apresenta um acréscimo na temperatura do ambiente de apenas $0,3{ }^{\circ} \mathrm{C}$ a $0,6^{\circ} \mathrm{C}$ em relação ao caso Dormitório - Temp. solo $+2{ }^{\circ} \mathrm{C}$. Essa pequena diferença ocorre porque a temperatura do solo no caso Dormitório - Temp. solo $+2{ }^{\circ} \mathrm{C}$ é de 29,0 ${ }^{\circ} \mathrm{C}$, enquanto a temperatura média do 
ambiente é de $30,0^{\circ} \mathrm{C}$. Assim, a proximidade entre as duas temperaturas gera uma dissipação do calor menor através do piso do ambiente.

A Tabela 7 mostra que nenhum dos casos simulados para o clima de São Luís atendeu ao critério do desempenho térmico mínimo de verão da NBR15575-1 (ABNT, 2013a).

\section{Aplicação dos limites do procedimento simplificado}

As Figura 6, 7 e 8 apresentam a avaliação do desempenho térmico da edificação com o limite definido no procedimento simplificado para a transmitância térmica da parede, para as cidades de Curitiba, Florianópolis e São Luís respectivamente.

Tabela 6-Contato com o solo - dia típico de verão e inverno para o clima de Florianópolis

\begin{tabular}{lcc}
\hline \multirow{2}{*}{ Casos } & \multicolumn{2}{c}{ Nível de desempenho NBR 15575-1(ABNT, 2013a) } \\
\cline { 2 - 3 } & Dia típico de verão & Dia típico de inverno \\
\hline Dormitório - Base & Mínimo & Mínimo \\
Dormitório - Temp. solo $+2{ }^{\circ} \mathrm{C}$ & Não atende ao nível mínimo & Intermediário \\
Dormitório - Temp. solo $-2{ }^{\circ} \mathrm{C}$ & Mínimo & Mínimo \\
Dormitório - Piso adiabático & Não atende ao nível mínimo & Não atende ao nível mínimo \\
\hline
\end{tabular}

Figura 5- Influência do contato com o solo no desempenho do dormitório no dia típico de verão para o clima de São Luís

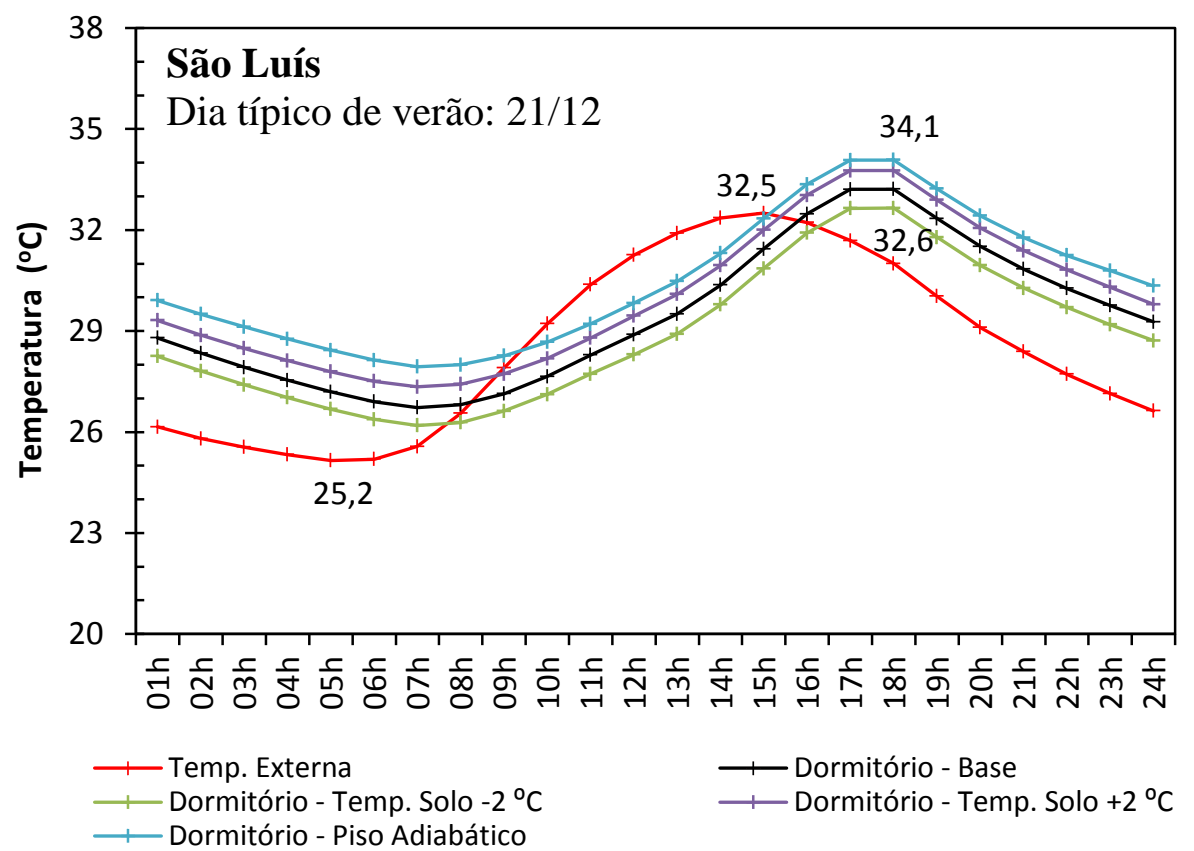

Tabela 7-Contato com o solo - dia típico de verão para o clima de São Luís

\begin{tabular}{lc}
\hline \multicolumn{1}{c}{ Casos } & Nível de desempenho NBR 15575-1 (ABNT, 2013a) \\
\hline Dormitório - Base & Não atende ao nível mínimo \\
Dormitório - Temp. solo $+2{ }^{\circ} \mathrm{C}$ & Não atende ao nível mínimo \\
Dormitório - Temp. solo $-2{ }^{\circ} \mathrm{C}$ & Não atende ao nível mínimo \\
Dormitório - Piso adiabático & Não atende ao nível mínimo \\
\hline
\end{tabular}

92 Sorgato, M. J.; Melo, A. P.; Marinoski, D. L.; Lamberts, R 
Figura 6 - Avaliação da edificação com o limite do procedimento simplificado no dia típico de verão e inverno de Curitiba
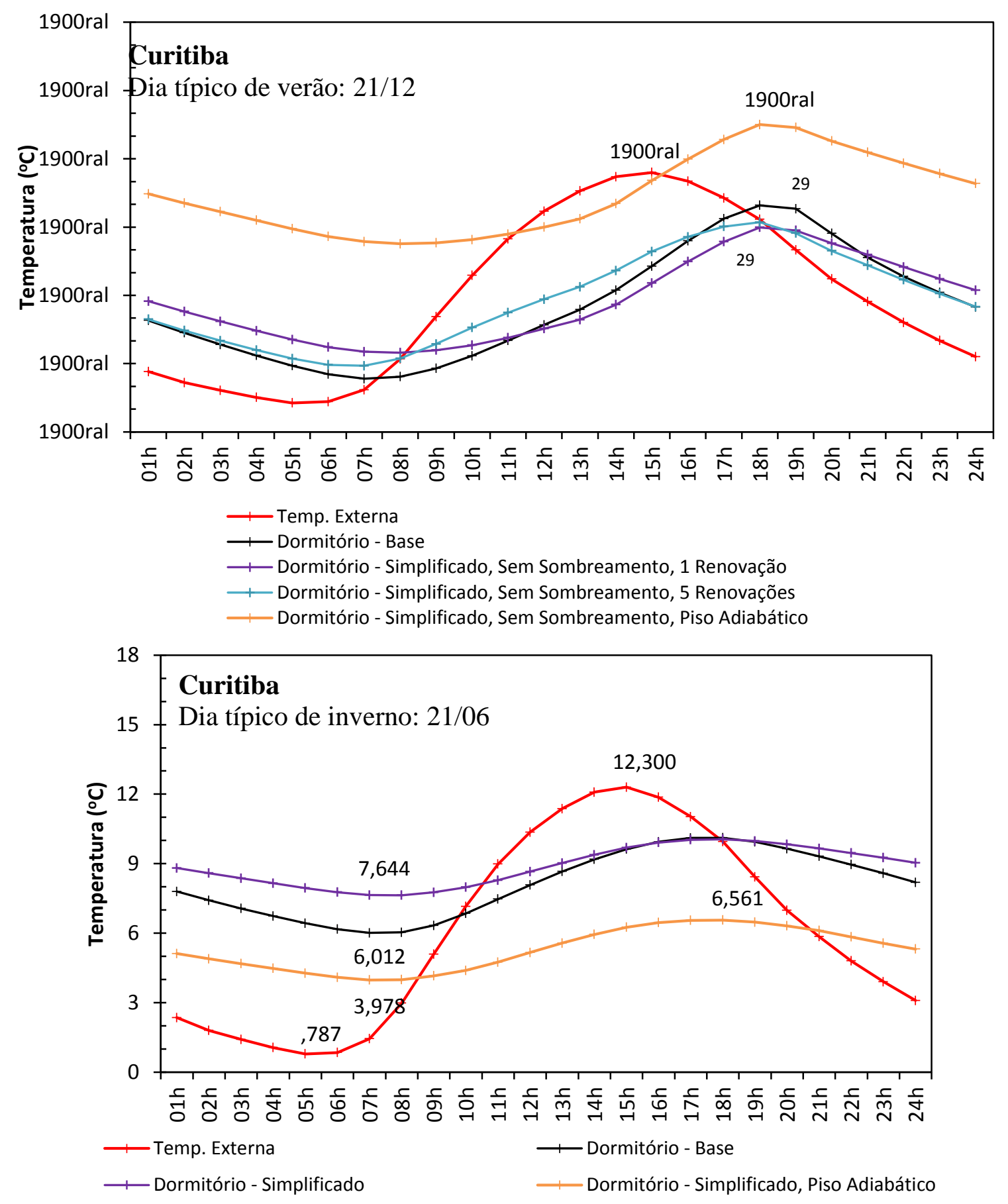
Tabela 8 - Procedimento simplificado - dia típico de verão e inverno de Curitiba

\begin{tabular}{lc}
\hline \multicolumn{1}{c}{ Casos dia típico de verão } & $\begin{array}{c}\text { Nível de desempenho NBR 15575- } \\
\text { 1(ABNT, 2013a) }\end{array}$ \\
\hline $\begin{array}{l}\text { Dormitório - Base } \\
\text { Dormitório - Simplificado, sem sombreamento, 1 renovação }\end{array}$ & Intermediário \\
$\begin{array}{l}\text { Dormitório - Simplificado, sem sombreamento, 5 renovações } \\
\text { Dormitório - Simplificado, semsombreamento, piso adiabático }\end{array}$ & Intermediário \\
\hline \multicolumn{1}{c}{ Casos dia típico de inverno } & Intermediário \\
& Não atende ao nível mínimo \\
\hline Dormitório - Base de desempenho NBR 15575- \\
Dormitório-Simplificado & 1(ABNT, 2013a) \\
Dormitório-Simplificado, piso adiabático & Mínimo \\
\hline
\end{tabular}

Observa-se que no dia típico de verão para o clima de Curitiba (Figura 6), a temperatura máxima do Dormitório - Simplificado sem sombreamento com 1 renovação foi de $29,0{ }^{\circ} \mathrm{C}$, apresentando uma diferença de $2,4{ }^{\circ} \mathrm{C}$ entre a temperatura externa e a interna. $\mathrm{O}$ aumento da taxa de 1 renovação de ar para 5 renovações acresceu na temperatura máxima do ambiente $0,2{ }^{\circ} \mathrm{C}$. Nota-se que também há aumento na temperatura do ambiente no período das $9 \mathrm{~h}$ às $18 \mathrm{~h}$. Todos os casos simulados com o piso do ambiente em contato com o solo e o limite da transmitância térmica da parede do método simplificado atenderam ao critério de desempenho térmico mínimo da NBR 15575-1. Entretanto, para o caso Dormitório - Simplificado sem sombreamento e com piso adiabático, a temperatura máxima do ambiente $\left(33,5{ }^{\circ} \mathrm{C}\right)$ foi superior à temperatura máxima externa $\left(31,4{ }^{\circ} \mathrm{C}\right)$, não atendendo ao critério de desempenho térmico mínimo. Para o dia típico de inverno, o Dormitório - Simplificado apresentou diferença de $6,8^{\circ} \mathrm{C}$ entre a temperatura mínima do ambiente e a mínima externa; já a diferença no Dormitório - Base foi de $5,2{ }^{\circ} \mathrm{C}$. No Dormitório - Simplificado sem sombreamento com piso adiabático, a diferença da temperatura mínima interna e externa foi de $3,2^{\circ} \mathrm{C}$, caso que atendeu ao critério do desempenho térmico mínimo da NBR 15575. Na Tabela 8 são apresentados os níveis de desempenho térmico dos casos no dia típico de verão e inverno de Curitiba.

Percebe-se que, para o dia típico de verão para o clima de Florianópolis, no caso do Dormitório Simplificado sem sombreamento com 1 renovação, a temperatura máxima do dormitório foi de $32,8^{\circ} \mathrm{C}$ (Figura 7 , superior à temperatura externa $\left(32,7^{\circ} \mathrm{C}\right)$. Dessa forma, não atendeu ao critério do desempenho térmico mínimo da NBR 15575-1. A alteração da taxa de renovação de ar de 1 para 5 reduz a temperatura máxima do dormitório para $32,4{ }^{\circ} \mathrm{C}$. Observa-se que há aumento na temperatura interna no período das $8 \mathrm{~h}$ às $16 \mathrm{~h}$. Nessa condição, a edificação atende ao critério do desempenho térmico mínimo da norma. No entanto, o caso com piso adiabático (Dormitório Simplificado sem sombreamento com piso adiabático) apresentou a temperatura máxima do dormitório superior à temperatura externa em 3,6 ${ }^{\circ} \mathrm{C}$, não atendendo ao desempenho mínimo. No dia típico de inverno observa-se que a temperatura mínima do Dormitório - Simplificado com piso adiabático foi de $7,3^{\circ} \mathrm{C}$, apenas $1,2^{\circ} \mathrm{C}$ superior à temperatura mínima externa. Já a diferença entre a temperatura mínima do Dormitório - Simplificado e a temperatura mínima externa foi de $5,2^{\circ} \mathrm{C}$. Para o caso Dormitório - Base a diferença encontrada foi de $4,4{ }^{\circ} \mathrm{C}$. O Dormitório - Simplificado atendeu ao nível intermediário de desempenho térmico da NBR 15575-1 (ABNT, 2013a). Entretanto, o Dormitório -Simplificado com piso adiabático não atendeu ao critério mínimo de desempenho térmico da norma.

A Figura 9 apresenta o resumo dos níveis de desempenho térmico dos casos simulados com o limite do procedimento simplificado para o dia típico de verão e de inverno de Florianópolis.

No dia típico de verão para o clima de São Luís (Figura 8), observa-se que todos os casos simulados apresentaram temperatura máxima do dormitório superior à temperatura máxima externa $\left(32,5{ }^{\circ} \mathrm{C}\right)$. Mesmo no caso Dormitório Simplificado sem sombreamento com 5 renovações a temperatura máxima do ambiente foi de $32,8^{\circ} \mathrm{C}$, ou seja, $0,3{ }^{\circ} \mathrm{C}$ superior à temperatura máxima externa. $\mathrm{O}$ impacto do aumento da taxa de renovação de ar não melhora significativamente o desempenho térmico da edificação neste clima. Todos os casos simulados para São Luís (Tabela 10) não atenderam ao critério de desempenho térmico mínimo estabelecido na NBR 15575-1 (ABNT, 2013a). 
Figura 7 - Avaliação da edificação com o limite do procedimento simplificado no dia típico de verão e inverno de Florianópolis
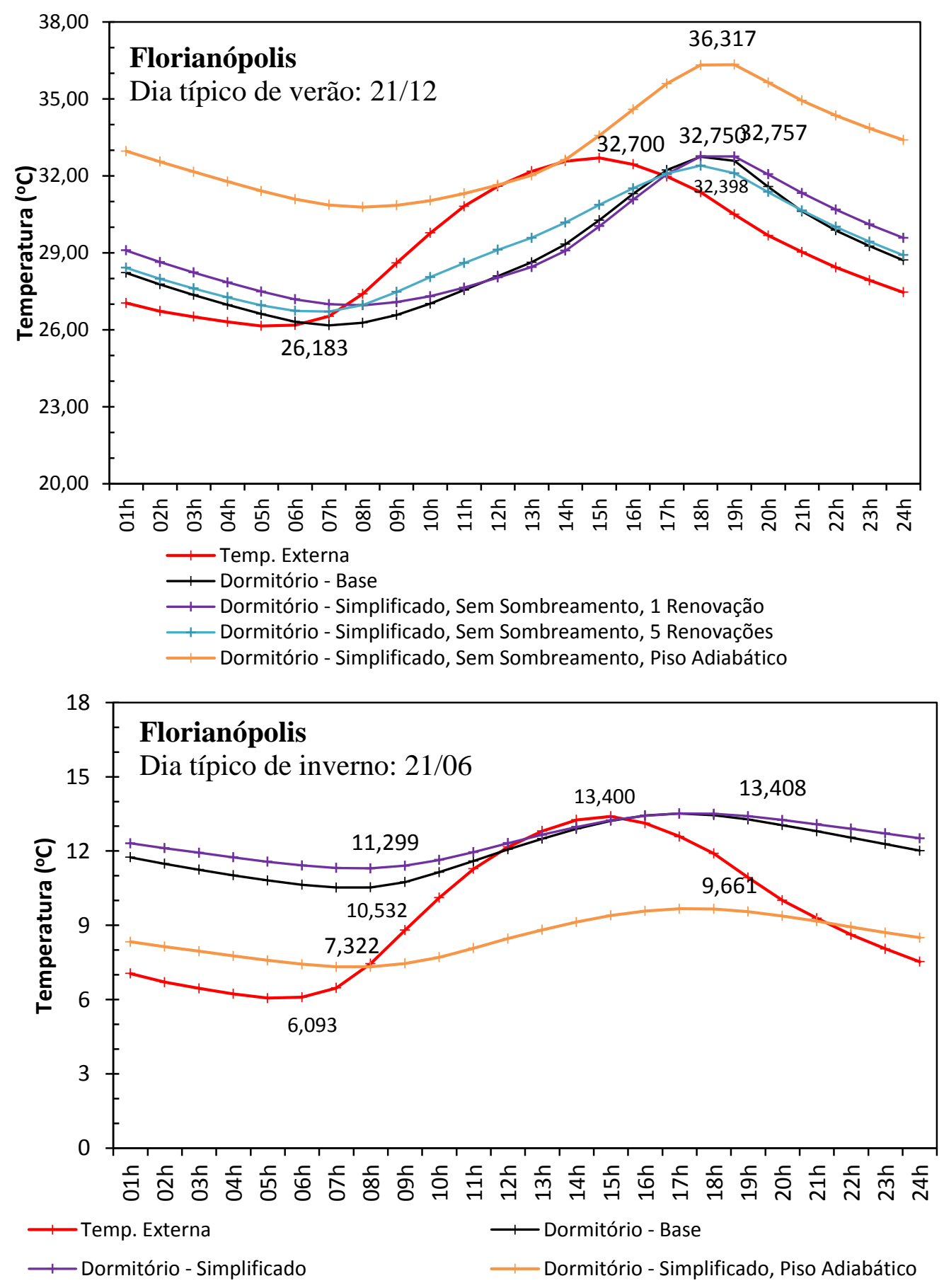
Tabela 9- Procedimento simplificado - dia típico de verão e inverno de Florianópolis

\begin{tabular}{lc}
\hline \multicolumn{1}{c}{ Casos dia típico de verão } & $\begin{array}{c}\text { Nível de desempenho NBR 15575- } \\
\text { 1(ABNT, 2013a) }\end{array}$ \\
\hline $\begin{array}{l}\text { Dormitório - Base } \\
\text { Dormitório - Simplificado, sem sombreamento, 1 renovação } \\
\text { Dormitório - Simplificado, sem sombreamento, 5 renovações } \\
\text { Dormitório - Simplificado, semsombreamento, piso adiabático }\end{array}$ & \begin{tabular}{c} 
Mínimo \\
\multicolumn{1}{c}{ Casos dia típico de inverno }
\end{tabular} \\
\hline & $\begin{array}{c}\text { Não atende ao nível mínimo } \\
\text { Nánimo }\end{array}$ \\
\hline $\begin{array}{l}\text { Dormitório - Base atende ao nível mínimo } \\
\text { Dormitório-Simplificado } \\
\text { Dormitório-Simplificado, piso adiabático }\end{array}$ & $\begin{array}{c}\text { Nível de desempenho NBR 15575- } \\
\text { 1(ABNT, 2013a) }\end{array}$ \\
\hline
\end{tabular}

Figura 8 - Avaliação da edificação com o limite do procedimento simplificado no dia típico de verão para o clima de São Luís

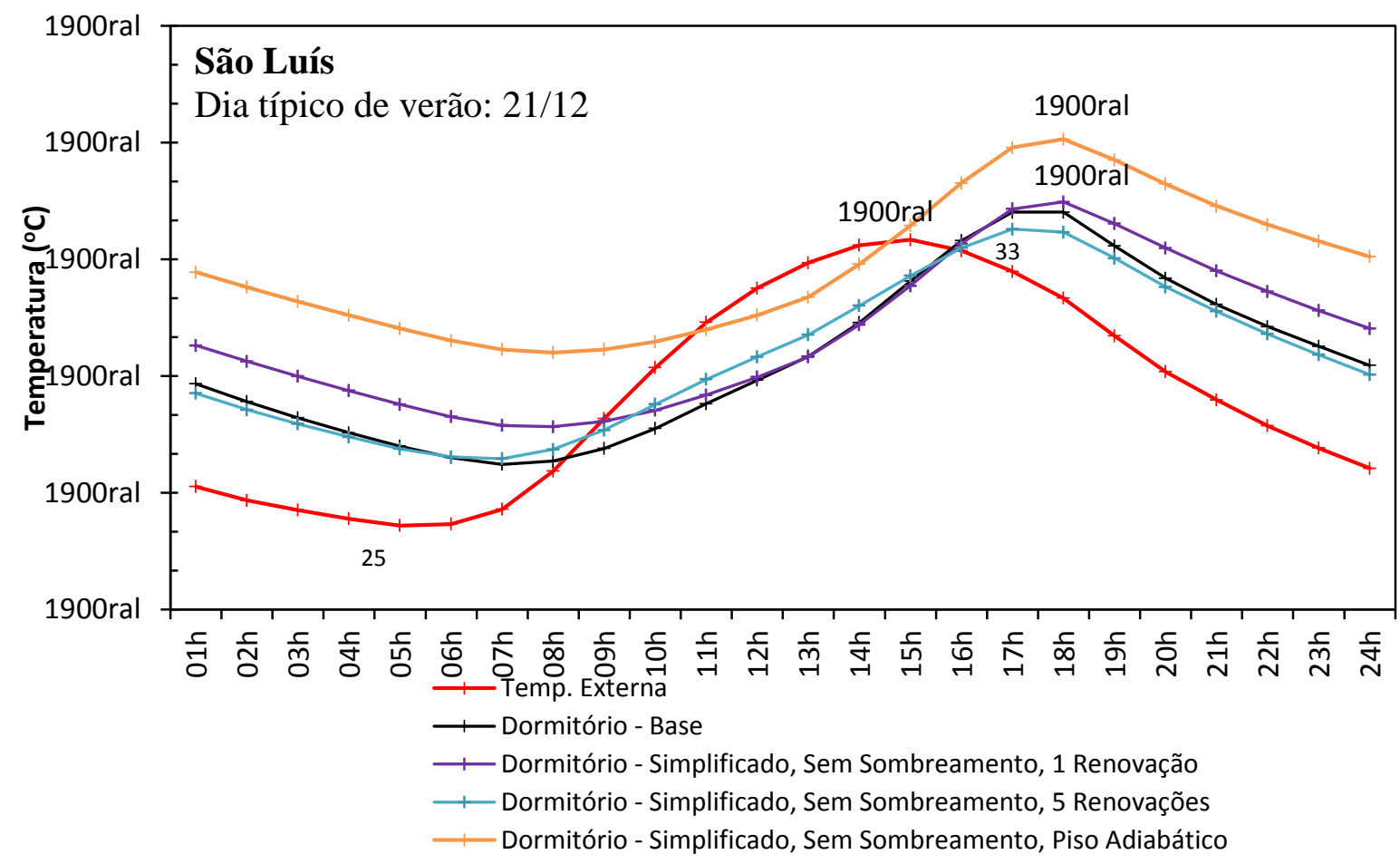

Tabela 10- Procedimento simplificado - dia típico de verão para o clima de São Luís

\begin{tabular}{lc}
\hline \multicolumn{1}{c}{ Casos } & $\begin{array}{c}\text { Nível de desempenho NBR 15575- } \\
\text { 1(ABNT, 2013a) }\end{array}$ \\
\hline Dormitório - Base & Não atende ao nível mínimo \\
Dormitório - Simplificado, sem sombreamento, 1 renovação & Não atende ao nível mínimo \\
Dormitório - Simplificado, sem sombreamento, 5 renovações & Não atende ao nível mínimo \\
Dormitório - Simplificado, semsombreamento, piso adiabático & Não atende ao nível mínimo \\
\hline
\end{tabular}

\section{Procedimento de simulação proposto}

No procedimento de simulação proposto são calculados os graus-hora de aquecimento $\left({ }^{\circ} \mathrm{Ch}_{\mathrm{A}}\right)$ para avaliar o desempenho da envoltória da edificação para a condição de frio (inverno). O desempenho para a condição de calor é avaliado através dos graus-hora de resfriamento $\left({ }^{\circ} \mathrm{Ch}_{\mathrm{R}}\right)$.

A Figura 9 apresenta os resultados da avaliação do desempenho térmico da edificação através do

96 Sorgato, M. J.; Melo, A. P.; Marinoski, D. L.; Lamberts, R 
procedimento de simulação proposto para o clima de Curitiba. Observa-se que no inverno o desempenho térmico da edificação com parede de concreto de $5 \mathrm{~cm}$ (parede sob avaliação) apresentou,em todos os ambientes, uma quantidade de ${ }^{\circ} \mathrm{Ch}_{\mathrm{A}}$ aproximadamente $30 \%$ superior à edificação com a parede de referência (Figura 9a). Para o verão, o clima de Curitiba apresenta 514 ${ }^{\circ} \mathrm{Ch}_{\mathrm{R}}$ externo. Nesta condição, os ambientes do caso da parede de referência resultaram em 0 (zero) ${ }^{\circ} \mathrm{Ch}_{\mathrm{R}}$, enquanto para a parede sob avaliação os ${ }^{\circ} \mathrm{Ch}_{\mathrm{R}}$ foram muito baixos (Figura $9 \mathrm{~b}$ ). Assim, a parede sob avaliação não atendeu ao desempenho mínimo estabelecido no procedimento de simulação proposto para a cidade de Curitiba, devido aos ${ }^{\circ} \mathrm{Ch}_{\mathrm{A}}$ e ${ }^{\circ} \mathrm{Ch}_{\mathrm{R}}$ superiores ao do caso da parede de referência.

A Figura 10 apresenta a avaliação do desempenho térmico da edificação para a cidade de Florianópolis. O clima da cidade de Florianópolis apresenta $6.030{ }^{\circ} \mathrm{Ch}_{\mathrm{A}}$ e $1.835^{\circ} \mathrm{Ch}_{\mathrm{R}}$. Os ambientes do caso com a parede sob avaliação apresentaram ${ }^{\circ} \mathrm{Ch}_{\mathrm{A}}$ aproximadamente $55 \%$ superior à edificação com a parede de referência (Figura 10a). No desempenho para verão do caso com a parede sob avaliação os ambientes apresentaram ${ }^{\circ} \mathrm{Ch}_{\mathrm{R}}$ entre $34 \%$ e $46 \%$ superior à edificação com a parede de referência (Figura 10 b).

Figura 9 - Desempenho térmico da edificação com a parede de referência versus edificação com parede sob avaliação no clima de Curitiba

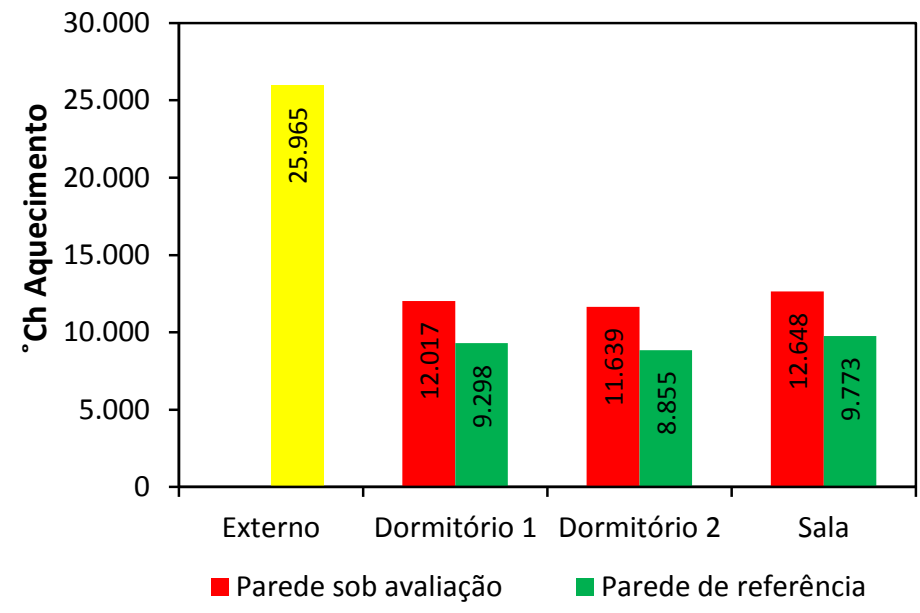

(a)

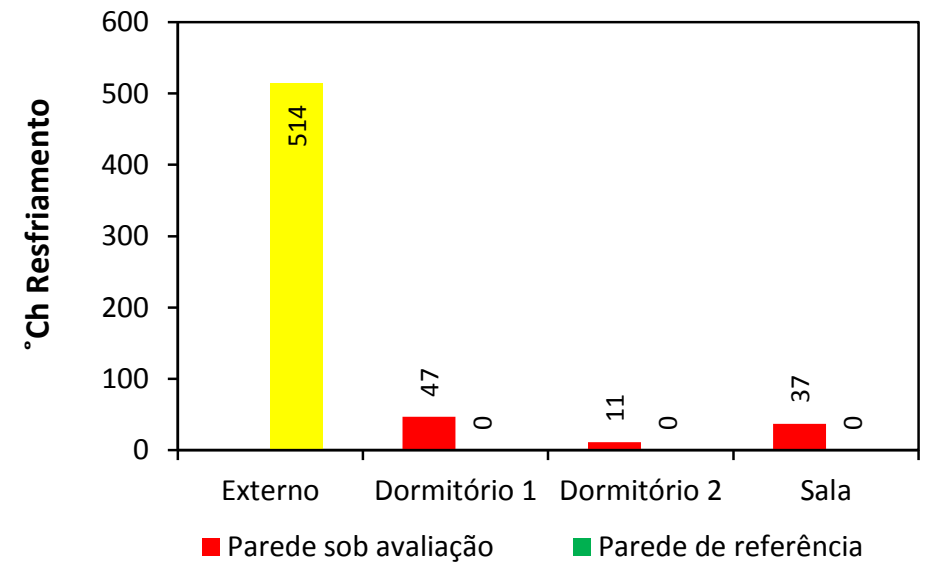

(b) 
Figura 10 - Desempenho térmico da edificação com a parede de referência versus edificação com parede sob avaliação para o clima de Florianópolis

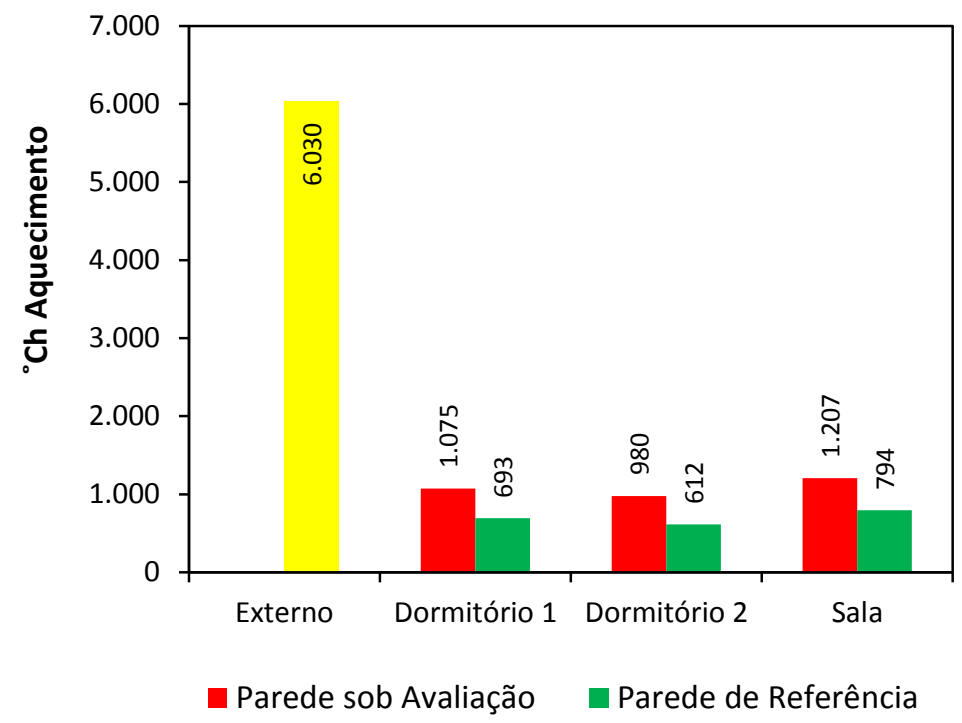

(a) Desempenho graus-hora de aquecimento $\left({ }^{\circ} \mathrm{Ch}_{\mathrm{A}}\right)$

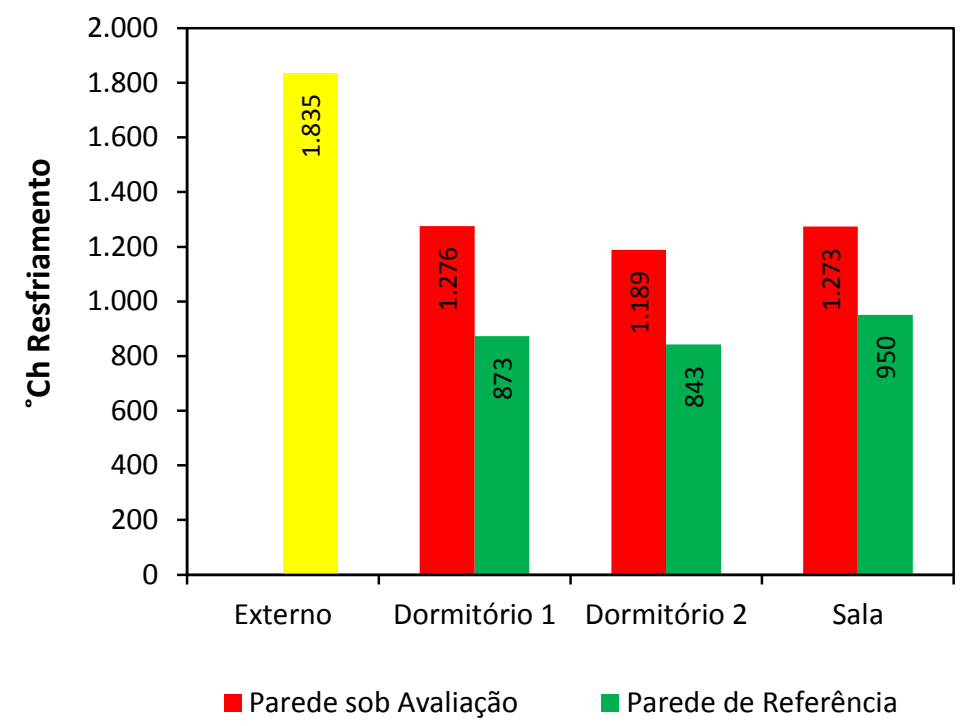

(b) Desempenho graus-hora de resfriamento $\left({ }^{\circ} \mathrm{Ch}_{\mathrm{R}}\right)$

O desempenho térmico da edificação com a parede de referência versus o da edificação com a parede sob avaliação (parede de concreto de $5 \mathrm{~cm}$ ) para o clima de São Luís é apresentado na Figura 11. O clima de São Luís apresenta $13.300{ }^{\circ} \mathrm{Ch}_{\mathrm{R}}$, e todos os ambientes do caso da parede sob avaliação apresentaram quantidade de ${ }^{\circ} \mathrm{Ch}_{\mathrm{R}}$ aproximadamente $9 \%$ superior ao clima externo. Observa-se ainda que apenas a sala do caso da parede de referência possui ${ }^{\circ} \mathrm{Ch}_{\mathrm{R}}$ de resfriamento superior ao clima externo. Ainda é possível notar que os ambientes do caso da parede sob avaliação apresentaram ${ }^{\circ} \mathrm{Ch}_{\mathrm{R}}$ de aproximadamente $8 \%$ superior aos ambientes do caso da parede de referência. Desse modo, a edificação com a parede sob avaliação não atendeu ao desempenho mínimo estabelecido no método de simulação proposto para o clima de São Luís. Alguns ambientes apresentaram ${ }^{\circ} \mathrm{Ch}_{\mathrm{R}}$ superiores ao externo, o que ocorre por causa de uma combinação de fatores, sendo o mais importante as cargas internas dos ambientes (ocupação, iluminação e equipamentos). 
Figura 11 - Desempenho térmico da edificação com a parede de referência versus edificação com parede sob avaliação para o clima de São Luís

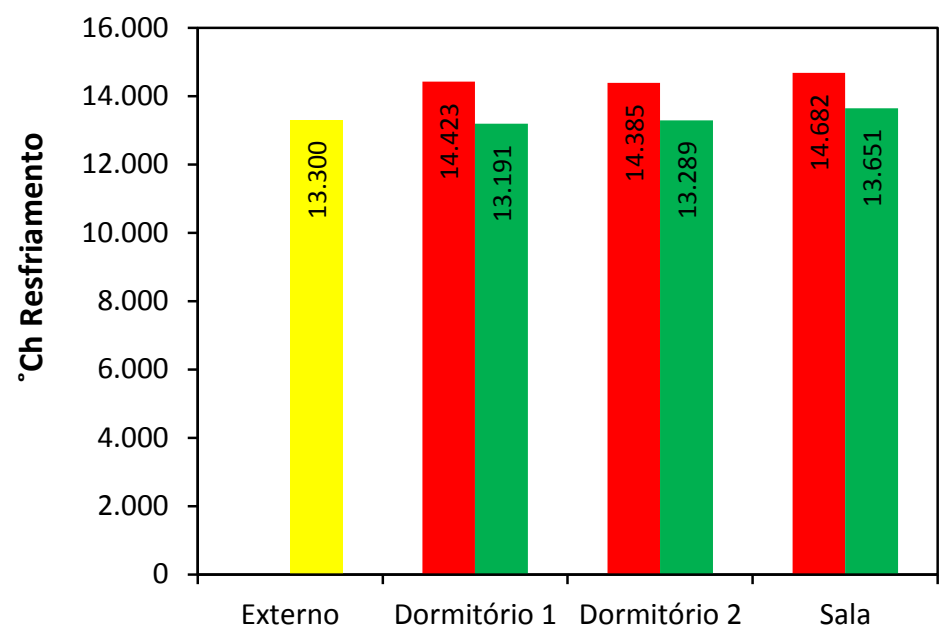

Parede sob Avaliação $\quad$ Parede de referência

\section{Conclusões}

Este estudo comparou o desempenho térmico de uma residência unifamiliar simulada mediante o procedimento presente da NBR-15575-1 (ABNT, 2013a)com o simulado com o procedimento proposto na consulta pública dessa mesma norma por Sorgato et al. (2012).

Os resultados das simulações através do procedimento de simulação da NBR 15575-1 (ABNT, 2013a) mostraram que as condições do piso da edificação em contato com o solo impactam significativamente no desempenho térmico da residência. Todos os casos simulados com o piso adiabático não atenderam ao critério de desempenho térmico mínimo da NBR 15575-1 (ABNT, 2013a). As variações na temperatura do solo de $\pm 2{ }^{\circ} \mathrm{C}$ implementadas neste estudo mostraram alterações nos resultados da avaliação do desempenho térmico da edificação no dia típico de verão e de inverno para o clima de Curitiba e Florianópolis. Já no dia típico de verão para o clima de São Luís, a condição de contato com o solo não influenciou significativamente $o$ desempenho, devido à pequena variação entre a temperatura do solo e a do ar no interior do ambiente. De qualquer modo, todos os casos simulados para o clima de São Luís não atenderam ao critério de desempenho térmico mínimo da norma.

O procedimento atual de simulação da norma 15575-1 (ABNT, 2013a) não apresenta nenhuma definição em relação à condição do piso da edificação. Com base nos resultados encontrados, pode-se observar que, dependendo da condição do piso adotada, a edificação pode ser aprovada ou reprovada. Isso indica que a norma deveria estipular a condição do piso da edificação a ser adotada na simulação, para que todos os casos fossem avaliados com o mesmo critério. A partir dos resultados obtidos, é possível constatar que os procedimentos de avaliação do desempenho térmico mínimo da NBR 15575 (simplificado e simulação) não apresentam equivalência.

Os resultados dos casos com as características do procedimento simplificado não atendem ao critério de desempenho térmico mínimo no dia típico de verão para o clima de Florianópolis e São Luís, quando avaliado pelo procedimento de simulação da norma. Apenas nos casos simulados com as características do procedimento simplificado para o dia típico de verão e inverno no clima de Curitiba foi possível observar equivalência entre os procedimentos. A alteração da taxa de renovação de ar de 1 para 5 trocas de ar por hora não melhora o desempenho térmico da edificação no dia típico de verão para o clima de São Luís, pois aumenta a taxa de renovação do ar nas horas que a temperatura externa é superior à temperatura do ambiente. Entretanto, no dia típico de verão para o clima de Florianópolis, a alteração da taxa de renovação de ar de 1 para 5 renovações viabiliza a aprovação da edificação com as características do procedimento simplificado. Para todos os casos simulados com o piso adiabático o desempenho térmico mínimo da NBR 15575-1 (ABNT, 2013a) não foi atendido. Assim, este estudo ressalta também a necessidade de um procedimento 
simplificado mais preciso e eficiente para a determinação do nível de desempenho térmico.

No procedimento de simulação proposto, o desempenho térmico da edificação é avaliado através dos graus-hora de aquecimento $\left({ }^{\circ} \mathrm{Ch}_{\mathrm{A}}\right)$ para a condição do inverno e dos graus-hora de resfriamento $\left({ }^{\circ} \mathrm{Ch}_{\mathrm{R}}\right)$ para a condição do verão. A avaliação é realizada por meio da comparação do desempenho térmico da edificação sob avaliação com o desempenho térmico da edificação de referência. Assim, o procedimento proposto possibilita que a edificação seja simulada e analisada próximo da realidade de uso, considerando os hábitos e as preferências dos usuários em relação à operação da edificação.

Com a aplicação do procedimento de simulação vigente na NBR 15575-1 (ABNT, 2013a), observou-se que o sistema construtivo com paredes de concreto $(5 \mathrm{~cm}$ de espessura) atende ao critério de desempenho térmico mínimo para os dias típicos do clima de Curitiba e Florianópolis, mas apresentando desempenho insatisfatório para o dia típico do clima de São Luís. Entretanto, os resultados das simulações mostraram que a edificação com esse mesmo sistema apresentou desempenho térmico insatisfatório em relação à edificação de referência do procedimento proposto. Através do procedimento de simulação proposto por Sorgato et al. (2012), o desempenho térmico da edificação deve ser equivalente ao desempenho do procedimento simplificado, de forma a garantir um nível mínimo de desempenho térmico para as edificações residenciais.

Considerando que o procedimento simplificado foi desenvolvido com base em levantamentos de edificações residenciais brasileiras, seria correto esperar que ambos os procedimentos (simplificado e simulação) levassem a resultados similares, ou na mesma ordem de grandeza, o que não aconteceu nos casos comparados. Além disso, o procedimento de simulação vigente na NBR 15575-1 (ABNT, 2013a) não considera alguns parâmetros importantes que influenciam no desempenho térmico das edificações residenciais, como cargas térmicas internas, condições de contato com o solo e ventilação natural. Com base nos resultados deste estudo, observa-se que há necessidade de aperfeiçoar o atual procedimento de simulação da norma NBR 15575-1 (ABNT, 2013a), para avaliar as edificações considerando a realidade de uso, como os hábitos e preferências culturais da população de cada região do Brasil.

\section{Referências}

ASSOCIAÇÃO BRASILEIRA DE NORMAS TÉCNICAS. NBR 15575-1: edifícios habitacionais: desempenho: parte 1: requisitos gerais. Rio de Janeiro, 2013a.

\section{ASSOCIAÇÃO BRASILEIRA DE NORMAS}

TÉCNICAS. NBR 15575-4: edifícios

habitacionais: desempenho: parte 4: sistemas de vedações verticais externas e internas. Rio de Janeiro, 2013b.

\section{ASSOCIAÇÃO BRASILEIRA DE NORMAS} TÉCNICAS. NBR 15575-5: edifícios

habitacionais: desempenho: parte 5: requisitos para sistemas de coberturas. Rio de Janeiro, 2013c.

AMERICAN SOCIETY OF HEATING, REFRIGERATING AND AIR-CONDITIONING ENGINEERS. ASHRAE 90.1: energy standard for buildings except low-rise residential buildings. Atlanta, GA: ASHRAE, 1989.

\section{AMERICAN SOCIETY OF HEATING, REFRIGERATING AND AIR-CONDITIONING} ENGINEERS. ASHRAE 140: stadard method of test for the evaluation of building energy analys computer programs. Atlanta, GA: ASHRAE, 2011.

BRITO, A. C. et al.Contribuições Para o Aprimoramento da NBR 15575 Referente ao Método Simplificado de Avaliação de Desempenho Térmico de Edifícios. In: Encontro Nacional de Tecnologia do Ambiente Construído. 14., Juiz de Fora, 2012. Anais... Juiz de Fora: ANTAC, 2012.

DEPARTMENT OF ENERGY. Programa EnergyPlus - versão 7.2. Disponível em: <http://apps1.eere.energy.gov/buildings/energyplu s/>. Acesso em: 18 out. 2012.

FRANÇA. Arrêté du 13 avril 1988, relatif aux équipements et aux caractéristiques thermiques dans les bâtiments à usage de bureaux ou de commerce. Journal Officiel de la République Française, Paris, 13 avril 1988.

GOUlart, S. V. G. Dados Climáticos Para Avaliação de Desempenho Térmico em Florianópolis. Florianópolis, 1993. 124 f. Dissertação (Mestrado em engenharia Civil) Programa de Pós-Graduação em Engenharia Civil, Universidade Federal de Santa Catarina, Florianópolis, 1993.

HENSEN, J. L. M.; LAMBERTS, R. Building Performance Simulation For Design and Operation. New York: Spon Press, 2011. 
JANDA, K. B.; BUSCH, J. F. Worldwide Status of Energy Standards For Buildings. Summer Study on Energy Efficiency in Buildings, Berkeley, v. 6,p. 103-105, 1992.

GRIGOLETTI, G. C.; SATTLER, M. A. Método de Avaliação Global de Desempenho Higrotérmico de Habitações de Interesse Social Para Porto Alegre, RS, Brasil. Ambiente Construído, Porto Alegre, v. 10, n. 2, p. 101-114, abr./jun. 2010.

LOURA, R. M.; ASSIS, E. S.; BASTOS, L. E. G. Análise Comparativa Entre Resultados de Desempenho Térmico de Envoltórias de Edifício Residencial Gerados Por Diferentes Normas Brasileiras.In: ENCONTRO NACIONAL DE CONFORTO NO AMBIENTE CONSTRUÍDO, 11., Búzios, 2011. Anais... Búzios, 2011.

MARQUES, T. H. T.; CHVATAL, K. M. S. A Review of the Brazilian NBR15575 Norm: applying the simulation and simplified methods for evaluating a social house thermal performance. In: SYMPOSIUM ON SIMULATION FOR ARCHITECTURE AND URBAN DESIGN, 4., San Diego, 2013.Proceedings...San Diego, 2013.
MAZZAFERRO, L. et al. Manual de Simulação Computacional de Edifícios Com Uso do PréProcessador Slab no Programa EnergyPlus. Florianópolis: LABEEE, 2014.

OLIVEIRA, R. D.; SOUZA, R. V. G.; SILVA, R. $M$. Desempenho Térmico: qual valor devemos atender para a legislação brasileira? In: ENCONTRO NACIONAL DE CONFORTO NO AMBIENTE CONSTRUÍDO, 12., Brasília, 2013.Anais... Brasília: ANTAC, 2013.

SORGATO, M. J. et al. Nota Técnica Referente à Avaliação Para a Norma de Desempenho NBR 15575 em Consulta Pública. Florianópolis: LABEEE, 2012.

SORGATO, M. J.; MELO, A. P.; LAMBERTS, R. Análise do Método de Simulação de Desempenho Térmico da Norma NBR 15575. In: ENCONTRO NACIONAL DE CONFORTO NO AMBIENTE CONSTRUÍDO, 12., Brasília, 2013.Anais... Brasília: ANTAC, 2013.

Marcio José Sorgato

Laboratório de Eficiência Energética em Edificações | Universidade Federal de Santa Catarina | Campus Universitário Trindade | Florianópolis - SC - Brasil | Caixa-Postal 476 | CEP 88040-970 | Tel.: (48) 3721-5185 | E-mail: sorgatomarcio@yahoo.com.br

Ana Paula Melo

Laboratório de Eficiência Energética em Edificações | Universidade Federal de Santa Catarina | E-mail: apaula_melo@hotmail.com

Deivis Luís Marinoski

Laboratório de Eficiência Energética em Edificações | Universidade Federal de Santa Catarina | E-mail: deivis.marinoski@ufsc.br

Roberto Lamberts

Laboratório de Eficiência Energética em Edificações | Universidade Federal de Santa Catarina | Tel.: (48) 3721-2390 |

E-mail: roberto.lamberts@ufsc.br

Revista Ambiente Construído

Associação Nacional de Tecnologia do Ambiente Construído

Av. Osvaldo Aranha, $99-3^{\circ}$ andar, Centro

Porto Alegre - RS - Brasil

CEP $90035-190$

Telefone: +55 (51) 3308-4084

Fax: +55 (51) 3308-4054

www.seer.ufrgs.br/ambienteconstruido

E-mail: ambienteconstruido@ufrgs.br 